\title{
Reinvestigation of tryptophan-dehydrobutyrine diketopiperazine structure
}

\author{
Carmen Avendaño,* Nieves Cabezas, Elena de la Cuesta, and J. Francisco González \\ Departamento de Química Orgánica y Farmacéutica, Facultad de Farmacia, Universidad \\ Complutense, 28040 Madrid (Spain) \\ E-mail: avendano@farm.ucm.es
}

\section{Dedicated to Professors José Elguero and Pedro Molina on the occasion of their $70^{\text {th }}$ and $60^{\text {th }}$ birthdays}

(received 14 Dec 04; accepted 12 Jan 05; published on the web 20 Jan 05)

\begin{abstract}
Reinvestigation of the title natural product's structure (1) has shown the easy racemization of the Trp-stereocenter in some derivatives of cyclo-L-Trp-Gly. The here described synthesis of compound 2, a regioisomer of $\mathbf{1}$ with the $\mathrm{N}$-methyl group on the nitrogen adjacent to the ethylidene side-chain, permits us to conclude that structure $\mathbf{1}$ was correct.
\end{abstract}

Keywords: Piperazinediones, TDD, N-acetylation, aldol-type condensation

\section{Introduction}

Cytotoxic anticancer drugs elicit cellular stress responses which frequently produce a drugresistant phenotype. One important mechanism of resistance of tumor cells to chemotherapeutic agents is the overexpression of dimer proteins of the glutathione-S-transferase family (GSTs). ${ }^{1}$ Thus, alkylating agents such as nitrogen mustards, cyclophosphamide, chlorambucil or melphalan, and other electrophile antitumor drugs such as busulfan or cis-platin, alter the expression of a number of genes that control glutathione and its associated enzymes, and many cancers show different distributions of GST isozymes compared to those seen in normal tissues. This knowledge suggests that selective GST inhibitors could provide potentiation of these chemotherapeutic agents. ${ }^{2}$ The main role of GSTs is to promote the neutralization of electrophilic toxins by the intracellular tripeptide glutathione ( $\gamma$-glutamylcysteinylglycine) ${ }^{3}$ but these enzymes are also catalysts of eicosanoid biosynthesis, a mechanism that may also be important in anticancer chemotherapy owing to the involvement of those compounds in the control of cellular division. ${ }^{4}$ In summary, inhibitors of glutathione synthesis (such as Lbuthionine sulfoximine ${ }^{5}$ ) and GTS-inhibitors, ${ }^{6}$ may help to prevent resistance to some antitumor 
agents. In fact, it has been shown that drugs like the diuretic ethacrynic acid or the anti-asthmatic compound piriprost, ${ }^{1,7}$ as well as some natural products, ${ }^{8 \mathrm{a}, \mathrm{b}}$ potentiate the anticancer activity of alkylating agents because of their inhibitory effects on glutathione detoxification. Tryptophandehydrobutyrine diketopiperazine (TDD, 1), a fungal metabolite isolated from Streptomyces spectabilis and Streptomyces sp. MI513-bF5, is one of these natural products whose structure was reported in 1974 without a clear assignment of the configuration of the C-(2)- stereocenter and the stereochemistry of the exocyclic double bond. ${ }^{8 c, 9 a}$ Owing to our interest in inhibitors of resistances to antitumor agents, ${ }^{10}$ and the experience in aldol reactions with diketopiperazines, ${ }^{11}$ we investigated the synthesis of $\mathbf{1}$ by condensation of acetaldehyde with $\mathrm{N}$-acetyl derivatives of $N^{1}$-methyl-cyclo-L-Trp-Gly by using a variety of reaction conditions. Rather unexpectedly, we only obtained $N$-deacetylation of the starting compound. This reaction failure, that was attributed to the steric constraints imposed by the $N^{1}$-methyl and the 6-(3-indolylmethyl) substituents, moved us to prepare compound 1 and its E-isomer by dehydration of $N^{1}$-methyl-cyclo-L-Trp-LThr (Scheme 1). ${ }^{9 b}$
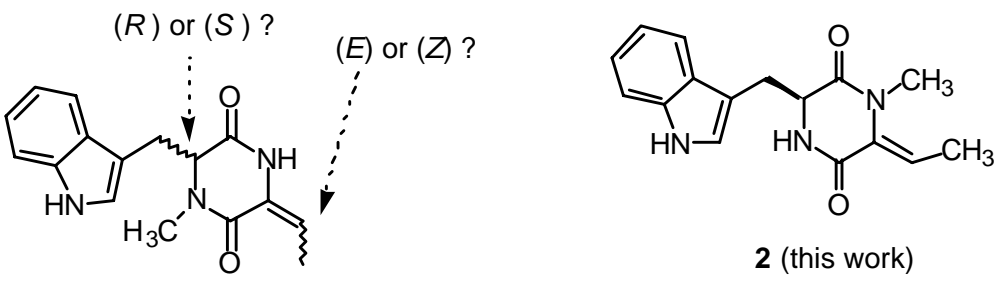

1 (ref. 9a)

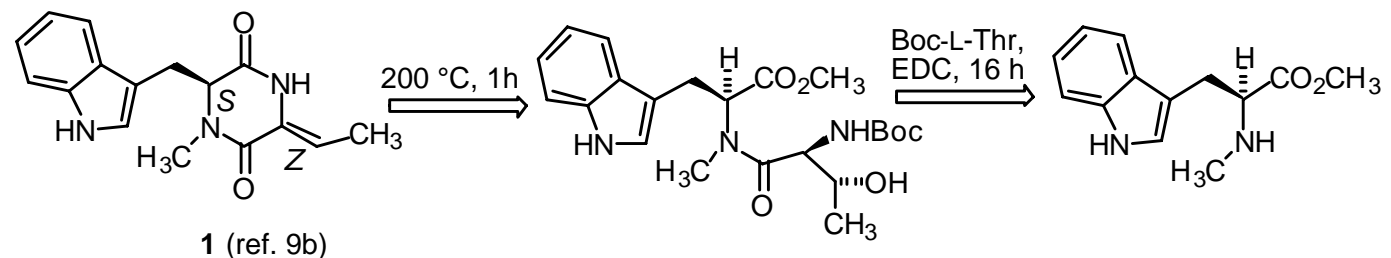

Scheme 1. Reported and proposed structures for TDD.

The chemical shifts of the vinylic protons in the $Z$ - and $E$ - isomers of $\mathbf{1}$ thus obtained, as well as the optical activity of the $Z$ - isomer, supported the (6-S, Z)- configuration for this compound, but we found slight discrepancies between its melting point and some of its NMR and mass spectra data from those described for the natural product (Table 1).

From these findings, we propose that the correct structure of TDD could be $\mathbf{2}$ instead of $\mathbf{1}$. The synthesis of compound 2, a regioisomer of $\mathbf{1}$ with the $\mathrm{N}$-methyl group on the nitrogen adjacent to the ethylidene side-chain, is described here. ${ }^{12}$ 
Table 1. Data reported for compound $\mathbf{1}$ in references $9 \mathbf{a}$ and $\mathbf{9 b}$

\begin{tabular}{|c|c|c|c|c|c|c|c|}
\hline Ref. & M.p. $\left({ }^{\circ} \mathrm{C}\right)^{\mathrm{a}}$ & {$[\alpha]_{D}^{b}$} & $\delta(\mathrm{ppm})$ & ${ }^{1} \mathrm{H}-\mathrm{NN}$ & $\mathrm{MR}^{\mathrm{c}}$ & $\delta(\mathrm{ppm}){ }^{13} \mathrm{C}-\mathrm{NMR}^{\mathrm{c}}$ & MS \\
\hline $9 \mathrm{a}$ & $121-123$ & +10 & $\begin{array}{l}9.05 \\
7.28 \\
5.41 \\
3.26,3\end{array}$ & $\begin{array}{l}8.19 \\
7.09 \\
4.25 \\
.04,1.00\end{array}$ & $\begin{array}{l}7.62, \\
6.77 \\
3.56, \\
0\end{array}$ & $\begin{array}{l}166.9,159.5,136.4, \\
127.5 .126 .4,124.7, \\
122.0,119.4,118.4, \\
113.0,111.0,107.6, \\
63.3,32.8,27.7\end{array}$ & $130,103,77$ \\
\hline $9 b$ & $191-192$ & +13 & $\begin{array}{l}8.10 \\
7.08, \\
5.41 \\
3.23,3\end{array}$ & $\begin{array}{l}7.58 \\
6.80 \\
4.24 \\
.06,0.84\end{array}$ & $\begin{array}{l}7.26, \\
6.74, \\
3.53, \\
4\end{array}$ & $\begin{array}{l}166.1,159.9,136.1, \\
127.4 .126 .1,124.5, \\
122.2,119.7,118.6, \\
111.7,110.7,107.9, \\
63.1,32.7,27.5\end{array}$ & $\begin{array}{l}284(\mathrm{MH}+, 1 \%), \\
283(\mathrm{M}+, 5 \%), 154 \\
\left(\mathrm{M}+-\mathrm{C}_{9} \mathrm{H}_{8} \mathrm{~N}, 100 \%\right), \\
130 \quad\left(\mathrm{C}_{9} \mathrm{H}_{8} \mathrm{~N}^{+},\right. \\
100 \%), 103,77\end{array}$ \\
\hline
\end{tabular}

${ }^{a}$ Recrystallized from acetone-cyclohexane.

${ }^{\mathrm{b}}$ Determined in $\mathrm{EtOH}(\mathrm{c}=1.1)^{9 \mathrm{a}}$ and $\mathrm{EtOH}(\mathrm{c}=0.03)^{9 \mathrm{~b}}$ solutions at $24.5^{\circ} \mathrm{C}$ and $21^{\circ} \mathrm{C}$, respectively.

${ }^{\mathrm{c}}$ Solvent $\mathrm{CDCl}_{3}$ in both cases.

\section{Results and Discussion}

The synthesis of compound 2 seemed, in principle, to be a simple problem. We knew that activation of cyclo-L-Trp-Gly (3, Scheme 2) by $\mathrm{N}$-acetylation with acetic anhydride gave the $N^{1}, N^{4}, N^{\prime}$-triacetylindolylmethylpiperazine-2,5-dione (4) and that this compound, through an aldol-type reaction with acetaldehyde in DMF and alumina-supported potassium fluoride as a base, ${ }^{13}$ afforded the ethylidene derivative 7 . This compound was supposed to be enantiomerically pure and seemed a good precursor of $\mathbf{2}$ by $\mathrm{N}$-methylation and subsequent deacetylation. However, when we looked to this reaction sequence in depth we began to suspect that, given the low optical rotation values of compounds 4 and $7,{ }^{9 \mathrm{~b}}$ the $\mathrm{N}$-acetylation and the subsequent condensation of $\mathbf{4}$ were not stereocontrolled as we had assumed. In fact, when the time for acetylation of $\mathbf{3}$ was increased to 12 hours, the compound $\mathbf{4}$ obtained was completely racemized.

To avoid the epimerization of the Trp-stereocenter, we decided to apply a procedure that we had developed previously for other synthetic objetives. ${ }^{14}$ Thus, compound 3 was converted into the more soluble $O, O$ '-disilyl derivative 5 , which was treated, without isolation, with acetyl chloride to give $(+)-\mathbf{6}$, with an optical rotation value $[\alpha]_{\mathrm{D}}^{21}=+120\left(\mathrm{c}=0.15, \mathrm{CHCl}_{3}\right)$. Its $(R)$ enantiomer was similarly obtained from cyclo-D-Trp-Gly and showed an optical rotation value $[\alpha]_{\mathrm{D}}^{21}=-120\left(\mathrm{c}=0.15, \mathrm{CHCl}_{3}\right)$.

We next attempted the acetylation of the indole $\mathrm{NH}$ group of $\mathbf{6}$, with acetyl chloride under different basic conditions, including phase-transfer catalysis, but with very disappointing results. Finally, we obtained the triacetyl derivative $(+)-4$, that showed an optical rotation $[\alpha]_{\mathrm{D}}{ }^{21}=+20(\mathrm{c}$ $\left.=0.3, \mathrm{CHCl}_{3}\right)$, by treatment of 6 with acetic anhydride. The enantiomeric purity of this product 
was corroborated by chiral chromatography on a Constametric 4100 system equipped with a Chiralcel OD chiral column, a UV-vis detector, hexane/iPrOH/Et ${ }_{2} \mathrm{NH}$ (9: 0.9: 0.1) as mobile phase, and the racemic mixture (+)-4/(-)-4 as a reference (see Experimental).

The different stereochemical outcome of the acetylation of compounds $(+)-3$ to give $( \pm)-4$ and (+)-6 to give (+)-4 can be explained by assuming that the presence of an $\mathrm{N}^{1}$-acetyl group in compound (+)-4 hampers the epimerization of the Trp- stereocenter by steric interference in intermediate $\mathbf{A}$, while in the case of the acetylation of compound (+)-3, racemization may take place on intermediate B (Figure 1).

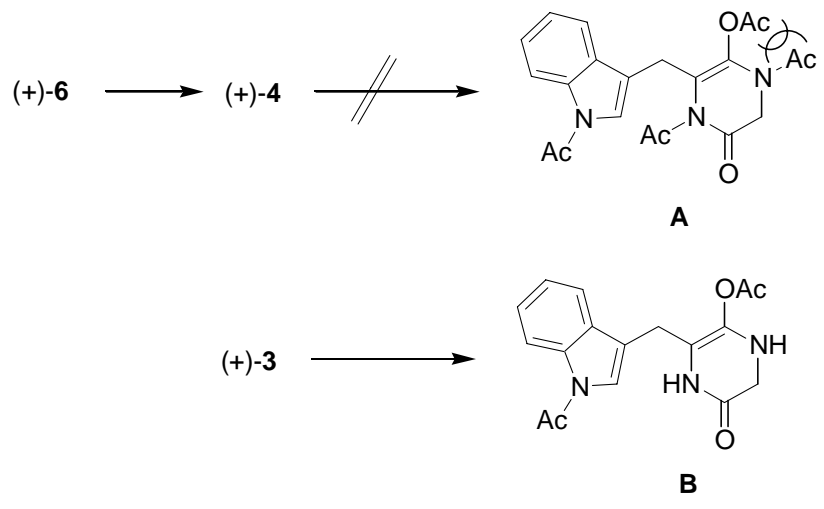

Figure 1. Rationalization of the stereocontrol in the acetylation of compounds $(+)-3$ and $(+)-6$.

In agreement with this hypothesis, we observed that the tryptophan stereocenter of $(+)-4$ did not withstand the basic conditions that were required for its aldol-type condensation with acetaldehyde and, because this reaction proceeds with the anchimeric assistance of the vicinal $N$ acetyl group leading to its final elimination, compound 7 was obtained as a racemized product (Scheme 2). ${ }^{15}$

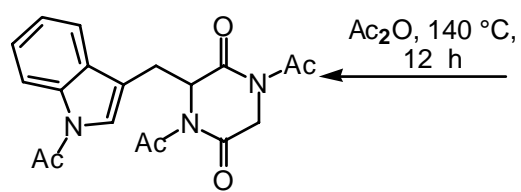

$( \pm)-4(99 \%)$

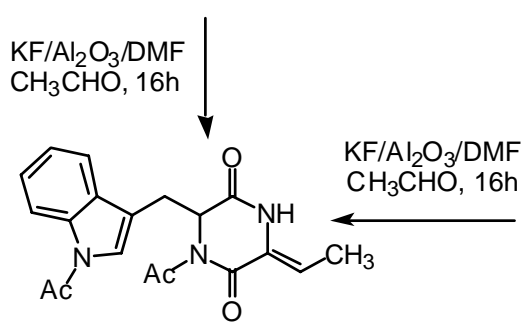

( \pm )-7 (86\%, major isomer)

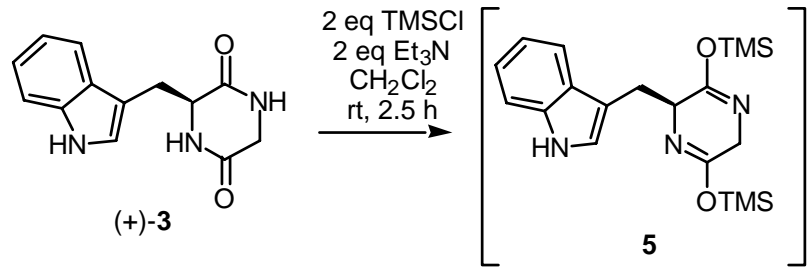

$\underset{\mathrm{rt}, 16 \mathrm{~h}}{2 \mathrm{eq} \mathrm{CH}_{3} \mathrm{COCl}}$

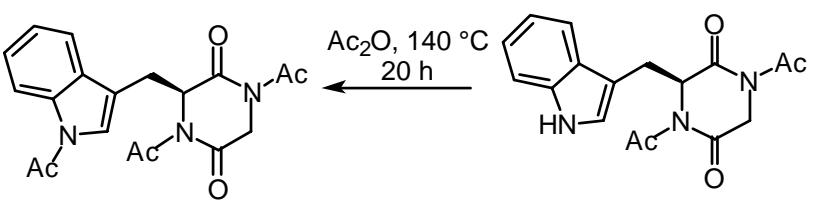

$(+)-4(93 \%)$

$(+)-6(70 \%)$

Scheme 2. Reinvestigation of the fate of the Trp-stereocenter in the N-acetylation/aldol- type condensation of cyclo-L-Trp-Gly. 
After considering the difficulties found in the preparation of homochiral $(+)-7$ and bearing in mind the fact that, with the exception of optical rotation, comparison of physical data of compounds 1 and 2 does not require enantiomeric purity, we undertook the preparation of $( \pm)-4$ by an alternative route, starting from non-chiral starting materials, in order to facilitate scale-up in its transformation into racemic compounds 7, 10 and 2 (Scheme 3). Compound ( \pm )-4 was now obtained in $75 \%$ overall yield by reduction of $\mathbf{8}$, through a four-step procedure that started with indole-3-carbaldehyde and $N^{1}, N^{4}$-diacetylpiperazine-2,5-dione (Scheme 3). ${ }^{11 \mathrm{~b}} \mathrm{~N}$-Methylation of compound 7, obtained by a second aldol-type condensation of 4 with acetaldehyde, required the total absence of water in order to avoid decomposition products. Fortunately, when anhydrous DMF and carefully dried sodium carbonate were used, compound $\mathbf{1 0}$ was obtained in very good yield. The chemical shift of it's $\alpha$-ethylidene proton $(\delta=5.70 \mathrm{ppm})$, as well as NOE experiments, confirmed the Z-configuration of its exocyclic double bond and, through a final deacetylation performed with hydrazine hydrate, we obtained the desired product $( \pm)-2$ with traces of its $E$ isomer.

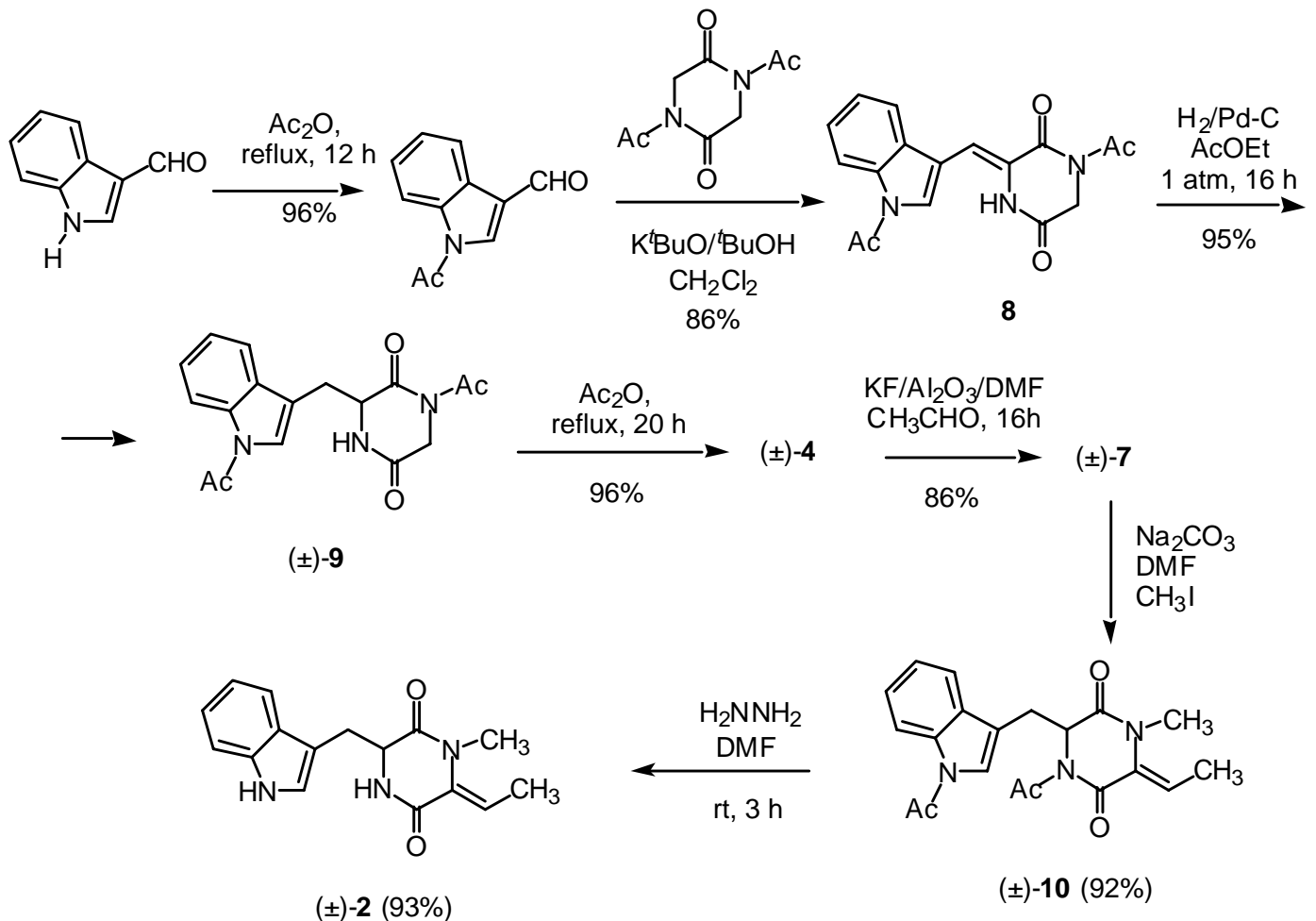

Scheme 3. Synthesis of compound 2 from indole-3-carboxaldehyde.

The significant differences observed by comparing data of compound 2 (Table 2) with those reported for TDD and the synthetic product 1 (Table 1) permit us to conclude here that, in spite of the previously reported discrepancies, ${ }^{9 b}$ structure $\mathbf{1}$ has to be the correct one for the natural product. 
Table 2. Data for compound 2

\begin{tabular}{lllll}
\hline M.p. $\left({ }^{\circ} \mathrm{C}\right)^{\mathrm{a}}$ & $\delta(\mathrm{ppm}){ }^{1} \mathrm{H}_{-N M R} \mathrm{~b}$ & $\delta(\mathrm{ppm}){ }^{13} \mathrm{C}-\mathrm{NMR}^{\mathrm{b}}$ & $\mathrm{MS}$ & \\
\hline $202-203{ }^{\circ} \mathrm{C}$ & $8.15,7.55,7.34$, & $167.3,163.9,136.4,132.2$, & $284\left(\mathrm{MH}^{+}, 3 \%\right), 283\left(\mathrm{M}^{+}\right.$, \\
& $7.30-7.10,6.99,5.96$, & $127.2 .124 .5,122.5,119.8$, & $12 \%)$, & $154 \quad\left(\mathrm{M}^{+}-\mathrm{C}_{9} \mathrm{H}_{8} \mathrm{~N}\right.$, \\
& $5.81,4.31,3.35,3.25$, & $118.7,118.4,111.1,108.9$, & $2 \%)$, & $130 \quad\left(\mathrm{C}_{9} \mathrm{H}_{8} \mathrm{~N}^{+}\right.$, \\
& $3.04,1.26$ & $56.1,34.8,30.3,12.9$ & $100 \%), 103,77$ & \\
\hline
\end{tabular}

${ }^{a}$ Recrystallized from acetone-cyclohexane.

${ }^{\mathrm{b}} \mathrm{CDCl}_{3}$ as solvent in both cases.

\section{Experimental Section}

(+)- 1,4-Diacetyl-3-(3-indolylmethyl)piperazine-2,5-dione (6). To a suspension of (+)-3 (0.4 g, $1.644 \mathrm{mmol})$ in anhydrous $\mathrm{CH}_{2} \mathrm{Cl}_{2}(30 \mathrm{~mL})$ under argon, $\mathrm{Et}_{3} \mathrm{~N}(0.84 \mathrm{~mL}, 6.576 \mathrm{mmol})$ was added, and then trimethylsilyl chloride $(0.92 \mathrm{~mL}, 6.576 \mathrm{mmol})$. The reaction mixture was stirred vigorously at RT until a solution was obtained. After addition of acetyl chloride $(0.19 \mathrm{~mL}$, $3.288 \mathrm{mmol}$ ) the mixture was stirred at RT for four days. The crude mixture was washed with brine $(3 \times 25 \mathrm{~mL})$, the organic layers dried over anhydrous sodium sulfate, and the solvent evaporated in vacuo. The residue was purified by flash chromatography (silica gel, 2:1 hexane/ethyl acetate) affording $0.363 \mathrm{~g}(70 \%$ yield $)$ of (+)-6. Mp: $192-195{ }^{\circ} \mathrm{C} ;[\alpha]_{\mathrm{D}}{ }^{21}=+120(\mathrm{c}$ $=0.15, \mathrm{CHCl}_{3}$ ). IR (film, $\left.\mathrm{CH}_{2} \mathrm{Cl}_{2}\right) 3405,1707 \mathrm{~cm}^{-1} .{ }^{1} \mathrm{H}-\mathrm{NMR}\left(\mathrm{CDCl}_{3}\right) \delta: 2.47\left(3 \mathrm{H}, \mathrm{s}, \mathrm{N}^{4}-\right.$ $\left.\mathrm{COCH}_{3}\right), 2.59\left(3 \mathrm{H}, \mathrm{s}, \mathrm{N}^{1}-\mathrm{COCH}_{3}\right), 2.26(1 \mathrm{H}, \mathrm{d}, \mathrm{J}=19.14 \mathrm{~Hz}, \mathrm{H}-6), 3.34(1 \mathrm{H}, \mathrm{dd}, \mathrm{J}=14.9$ and $5.3 \mathrm{~Hz}, \mathrm{H}-3 \mathrm{a}), 3.36(1 \mathrm{H}, \mathrm{dd}, \mathrm{J}=14.9$ and $3.4 \mathrm{~Hz}, \mathrm{H}-3 \mathrm{a}) 4.29(1 \mathrm{H}, \mathrm{d}, \mathrm{J}=19.14 \mathrm{~Hz}, \mathrm{H}-6), 5.41$ $(1 \mathrm{H}, \mathrm{m}, \mathrm{H}-3), 6.88\left(1 \mathrm{H}, \mathrm{d}, \mathrm{J}=2.45 \mathrm{~Hz}, \mathrm{H}-2^{\prime}\right), 7,13\left(2 \mathrm{H}, \mathrm{m}, \mathrm{H} 5^{\prime}-\mathrm{H}^{\prime}\right), 7.33(1 \mathrm{H}, \mathrm{d}, \mathrm{J}=8.1 \mathrm{~Hz}$, H-7'), $7.43\left(1 \mathrm{H}, \mathrm{d}, \mathrm{J}=7.9 \mathrm{~Hz}, \mathrm{H}-4^{\prime}\right) 8.14(1 \mathrm{H}, \mathrm{s}, \mathrm{NH}) ;{ }^{13} \mathrm{C}-\mathrm{NMR}\left(\mathrm{CDCl}_{3}\right) \delta: 27.1\left(N^{4}-\mathrm{COCH}_{3}\right)$, $27.3\left(N^{1}-\mathrm{COCH}_{3}\right), 28.9$ (C-3a), $46.3(\mathrm{C}-6), 59.1(\mathrm{C}-3), 108.8\left(\mathrm{C}-7^{\prime}\right), 111.5\left(\mathrm{C}-3^{\prime}\right), 118.2\left(\mathrm{C}-6^{\prime}\right)$, $120.5\left(\mathrm{C}-4^{\prime}\right), 123.2\left(\mathrm{C}-5^{\prime}\right), 124.2\left(\mathrm{C}-2^{\prime}\right), 126.6(\mathrm{C}-3 \mathrm{a}), 135.9(\mathrm{C}-7 \mathrm{a}), 166.2(\mathrm{C}(5)=\mathrm{O}), 168.8\left(N^{4}-\right.$ $\mathrm{CO}), 171.1\left(N^{1}-\mathrm{CO}\right), 171.5(\mathrm{C}(2)=\mathrm{O})$. Found: $\mathrm{C}, 62.45 ; \mathrm{H}, 5.20 ; \mathrm{N}, 12.85 . \mathrm{C}_{17} \mathrm{H}_{17} \mathrm{~N}_{3} \mathrm{O}_{4}$ requires: C, $62.38 ; \mathrm{H}, 5.23 ; \mathrm{N}, 12.84 \%$.

(+)- $N, N^{\prime}, N^{\prime \prime}$-Triacetyl-3-(3-indolylmethyl)piperazine-2,5-dione (4). $[\alpha]_{\mathrm{D}}{ }^{21}=+20(\mathrm{c}=0.3$, $\mathrm{CHCl}_{3}$ ). Compound (-)-4 was similarly obtained starting from (-)-3. For m.p, IR and NRM data of compounds 7 and 4 see reference $9 \mathrm{~b}$.

Synthesis of racemic compounds starting from indole-3-carboxaldeyde $( \pm)(Z)-N^{\prime}, N^{\prime \prime}-$ diacetyl-6-ethylidene-3-(3-indolylmethyl)piperazine-2,5-dione (7). To a solution of 1acetylindole-3-carboxaldehyde $(2.830 \mathrm{~g}, 15.1 \mathrm{mmol})$ and $N^{1}, N^{4}$-diacetylpiperazine-2,5-dione (3.287 g, $16.6 \mathrm{mmol})$ in dry $\mathrm{CH}_{2} \mathrm{Cl}_{2}(50 \mathrm{~mL})$ under an argon atmosphere, was added a $1 M$ solution of $\mathrm{K}^{t} \mathrm{OBu}$ in ${ }^{t} \mathrm{BuOH}(16.6 \mathrm{~mL}, 16.6 \mathrm{mmol})$. The mixture was stirred at $\mathrm{RT}$ for $18 \mathrm{~h}$ and then a saturated aqueous solution of $\mathrm{NH}_{4} \mathrm{Cl}(20 \mathrm{~mL})$ was added. The mixture was extracted with $\operatorname{AcOEt}(100 \mathrm{~mL} \times 3)$, and the extracts washed with $\mathrm{H}_{2} \mathrm{O}$ and then a saturated solution of $\mathrm{NaCl}$ in 
water, dried over anhydrous $\mathrm{Na}_{2} \mathrm{SO}_{4}$, filtered, and concentrated in vacuo to give 8 (4.2 g). A solution of 8 in methanol $(400 \mathrm{~mL})$, containing $10 \%$ palladium on carbon $(420 \mathrm{mg})$, was stirred vigorously under hydrogen ( 2 bars) for $20 \mathrm{~h}$. The catalyst was removed by filtration through Celite and the solvent evaporated to give $9(4.1 \mathrm{~g})$. A solution of this product in $\mathrm{Ac}_{2} \mathrm{O}$ was heated under reflux for $4 \mathrm{~h}$, then evaporated in vacuo to give 4 (5.1 g). This compound was purified by flash chromatography on silica gel with hexane/ethyl acetate $(6: 4)$, yielding $4.838 \mathrm{~g}$ of the pure product (87\%). A solution of $4(324 \mathrm{mg}, 0.78 \mathrm{mmol})$ and $40 \% \mathrm{KF} / \mathrm{Al}_{2} \mathrm{O}_{3}(3.44 \mathrm{mg}, 2.37 \mathrm{mmol})$ in anhydrous DMF $(30 \mathrm{~mL})$ was stirred at RT under argon for $15 \mathrm{~min}$. After cooling in ice-water, acetaldehyde $(0.09 \mathrm{~mL}, 1.76 \mathrm{mmol})$ was added and the mixture was stirred at $\mathrm{RT}$ for $24 \mathrm{~h}$, filtered, and evaporated, to give 7 (436 $\mathrm{mg})$. This compound was purified by flash chromatography on silica gel with hexane/ethyl acetate (4:6) as solvents yielding $262 \mathrm{mg}(95 \%)$ of the pure product. The mp, IR and NMR data of compounds $\mathbf{4}$ and $\mathbf{7}$ are described in reference $9 \mathrm{~b}$.

( \pm )-(Z)- $N^{4}, N^{\prime}$-Diacetyl-6-ethylidene-3-(3-indolylmethyl)-1-methylpiperazine-2,5-dione (10). A solution of 7 (38 mg, $0.11 \mathrm{mmol})$ in dry DMF was added to dried $\mathrm{Na}_{2} \mathrm{CO}_{3}(23 \mathrm{mg}, 0.22 \mathrm{mmol})$ and the mixture was stirred under argon at RT for $30 \mathrm{~min}$. Then $\mathrm{MeI}(40 \mu 1,0.64 \mathrm{mmol})$ was added, the reaction mixture stirred at RT for $24 \mathrm{~h}$, then extracted with AcOEt (10 mL x 3). The extracts were washed with $\mathrm{H}_{2} \mathrm{O}$ and saturated aq. $\mathrm{NaCl}$, dried over anhydrous $\mathrm{Na}_{2} \mathrm{SO}_{4}$, filtered, and concentrated in vacuo to give 10 (45 mg), which was purified by flash chromatography on silica gel with hexane/ethyl acetate (1:1) as solvents yielding (10) $36 \mathrm{mg}$ (92\%). An analytical sample was recrystallized from $\mathrm{CH}_{2} \mathrm{Cl}_{2}$ /hexane.

Data for 10: Off-white solid. Mp 152-154 ${ }^{\circ} \mathrm{C}\left(\mathrm{CH}_{2} \mathrm{Cl}_{2} /\right.$ hexane). IR ( $\left.\mathrm{NaCl}\right)$ v: 2932, 1704, 1682, and $1639 \mathrm{~cm}^{-1} . \mathrm{H}-\mathrm{NMR}\left(\mathrm{CDCl}_{3}, 250 \mathrm{MHz}\right) \delta: 8.37(1 \mathrm{H}, \mathrm{d}, J=7.7 \mathrm{~Hz}) ; 7.43(1 \mathrm{H}, \mathrm{dd}, J=6.9$ and $1.1 \mathrm{~Hz}) ; 7.34(1 \mathrm{H}$, ddd, $J=15.1,7.3$ and $1.2 \mathrm{~Hz}) ; 7.15(1 \mathrm{H}, \mathrm{dd}, J=15.1,7.5$ and $1.1 \mathrm{~Hz})$; $6.99(1 \mathrm{H}, \mathrm{s}) ; 5.70(1 \mathrm{H}, \mathrm{q}, J=7.8 \mathrm{~Hz}) ; 5.38(1 \mathrm{H}, \mathrm{dd}, J=5.4$ and $3.4 \mathrm{~Hz}) ; 3.46(1 \mathrm{H}, \mathrm{dd}, J=14.8$ and $3.4 \mathrm{~Hz}) ; 3.19(1 \mathrm{H}$, dd, $J=14.8$ and $5.4 \mathrm{~Hz}) ; 2.88(3 \mathrm{H}, \mathrm{s}) ; 2.59(3 \mathrm{H}, \mathrm{s}) ; 2.55(3 \mathrm{H}, \mathrm{s}) ; 0.93$ $(3 \mathrm{H}, \mathrm{d}, J=7.8 \mathrm{~Hz}) .{ }^{13} \mathrm{C}-\mathrm{NMR}\left(\mathrm{CDCl}_{3}, 63 \mathrm{MHz}\right) \delta: 172.3\left(\mathrm{~N}^{\prime}-\mathrm{COCH}_{3}\right) ; 168.4\left(N^{4}-\mathrm{COCH}_{3}\right) ; 166.5$ (C-2); 163.1 (C-5); 135.6 (C-7’a); 131.8 (C-3’a); 130.2 (C-6); 125.7 (C-2'); 125.6 (C-5'); 123.6 (C-4'); 121.9 (C-6’); 118.7 (C-7'); $116.6\left(\mathrm{CH}^{\prime}\right)$; 115.9 (C-3'); 56.8 (C-3); 34.4 (N-CH $) ; 27.9$ $\left(\mathrm{CH}_{2}\right) ; 27.1\left(N^{4}-\mathrm{COCH}_{3}\right) ; 23.8\left(N-\mathrm{COCH}_{3}\right) ; 12.9\left(\mathrm{CH}_{3}-\mathrm{CH}=\right)$. Anal. Calcd. for $\mathrm{C}_{20} \mathrm{H}_{21} \mathrm{~N}_{3} \mathrm{O}_{4}: \mathrm{C}$, 65.38; H, 5.76; N, 11.44. Found: C, 64.99; H, 5.67; N, 11.21\%.

( \pm )-(Z)-6-Ethylidene-3-(3-indolylmethyl)-1-methylpiperzine-2,5-dione (2). To a solution of $10(40 \mathrm{mg}, 0.11 \mathrm{mmol})$ in anhydrous $\operatorname{DMF}(0.7 \mathrm{~mL})$ at $0{ }^{\circ} \mathrm{C}$ was added hydrazine hydrate $(11 \mu \mathrm{l}$, $0.22 \mathrm{mmol}$ ); the mixture was stirred at RT under argon for $20 \mathrm{~h}$. The reaction was quenched by addition of ice and extracted with ethyl acetate $(10 \mathrm{~mL} \times 3)$, the extracts washed with $\mathrm{H}_{2} \mathrm{O}$, and saturated aq. $\mathrm{NaCl}$, dried over anhydrous $\mathrm{Na}_{2} \mathrm{SO}_{4}$, filtered, and concentrated in vacuo, to give 2 (32 mg, $93 \%$ ) which was recrystallized from acetone-cyclohexane.

Data for 2: Off-white solid, mp $202-203{ }^{\circ} \mathrm{C}$. IR (NaCl): 3272, 2918, 1683 and $1634 \mathrm{~cm}^{-1} .{ }^{1} \mathrm{H}-$ NMR $\left(\mathrm{CDCl}_{3}, 250 \mathrm{MHz}\right) \delta: 8.15(1 \mathrm{H}, \mathrm{ws}) ; 7.55(1 \mathrm{H}, \mathrm{d}, J=7.6 \mathrm{~Hz}) ; 7.34(1 \mathrm{H}, \mathrm{d}, J=8.0 \mathrm{~Hz}) ; 7.3$ - $7.1(2 \mathrm{H}, \mathrm{m}) ; 6.99(1 \mathrm{H}, \mathrm{s}) ; 5.96(1 \mathrm{H}, \mathrm{ws}) ; 5.81(1 \mathrm{H}, \mathrm{q}, J=7.8 \mathrm{~Hz}) ; 4.31(1 \mathrm{H}, \mathrm{m}) ; 3.35(1 \mathrm{H}$, dd, 
$J=14.6$ and $J=6.1 \mathrm{~Hz}) ; 3.25(1 \mathrm{H}, \mathrm{dd}, J=14.6$ and $J=4.3 \mathrm{~Hz}) ; 3.04(3 \mathrm{H}, \mathrm{s}) ; 1.26(3 \mathrm{H}, \mathrm{d}, J=$

$7.8 \mathrm{~Hz}) .{ }^{13} \mathrm{C}-\mathrm{NMR}\left(\mathrm{CDCl}_{3}, 125.76 \mathrm{MHz}\right) \delta: 167.3$ (C-2), 163.9 (C-5), 136.4 (C-7’a), 132.2 (C3'a), 127.2 (C-6), 124.5 (C-2'), 122.5 (C-5'), 119.8 (C-4'), 118.7 (C-6'), 118.4 (CH=), 111.1 (C3'), 108.9 (C-7'), 56.1 (C-3), $\left.34.8 \mathrm{~N}-\mathrm{CH}_{3}\right), 30.3\left(\mathrm{CH}_{2}\right), 12.9\left(\mathrm{CH}_{3}-\mathrm{CH}=\right){ }^{1} \mathrm{H}-\mathrm{NMR}(\mathrm{MeOD}, 250$ $\mathrm{MHz}) \delta: 7.41(1 \mathrm{H}, \mathrm{d}, J=7.9 \mathrm{~Hz}) ; 7.30(1 \mathrm{H}, \mathrm{d}, J=8.0 \mathrm{~Hz}) ; 7.08(1 \mathrm{H}, \mathrm{dd}, J=7.9$ and $7.0 \mathrm{~Hz})$; $6.97(1 \mathrm{H}, \mathrm{dd}, J=8.0$ and $7.0 \mathrm{~Hz}) ; 6.88(1 \mathrm{H}, \mathrm{s}) ; 5.36(1 \mathrm{H}, \mathrm{q}, J=7.7 \mathrm{~Hz}) ; 4.28(1 \mathrm{H.} \mathrm{m}) ; 3.46(1 \mathrm{H}$, $\mathrm{dd}, J=14.5$ and $J=3.0 \mathrm{~Hz}) ; 3.02(1 \mathrm{H}, \mathrm{dd}, J=14.5$ and $J=4.6 \mathrm{~Hz}) ; 2.83(3 \mathrm{H}, \mathrm{s}) ; 0.82(3 \mathrm{H}, \mathrm{d}, J$ $=7.7 \mathrm{~Hz}) .{ }^{13} \mathrm{C}-\mathrm{NMR}(\mathrm{MeOD}, 63 \mathrm{MHz}) \delta: 170.3$ (C-2); 166.1 (C-5); 138.5 (C-7'a); 133.3 (C3'a); 129.4 (C-6); 127.3 (C-2'); 122.83 (C-5'); 120.0 (C-4'); 119.6 (C-6’); 118.8 (CH=); 112.6 (C-3'); 108.7 (C-7'); 58.3 (C-3); $35.5\left(\mathrm{CH}_{2}\right) ; 32.0\left(\mathrm{~N}^{\prime} \mathrm{CH}_{3}\right) ; 13.1\left(\mathrm{CH}_{3}-\mathrm{CH}=\right)$. Anal. Calcd. for $\mathrm{C}_{16} \mathrm{H}_{17} \mathrm{~N}_{3} \mathrm{O}_{2}$ : C, 67. 83; H, 6.05; N, 14.83. Found: C, 67.54; H, 5.89; N, 14.67. MS: $284\left(\mathrm{MH}^{+}\right.$; $\left.\mathrm{C}_{16} \mathrm{H}_{18} \mathrm{~N}_{3} \mathrm{O}^{+} ; 3 \%\right), 283\left(\mathrm{M}^{+} ; \mathrm{C}_{16} \mathrm{H}_{17} \mathrm{~N}_{3} \mathrm{O}^{+} ; 12 \%\right), 154\left(\mathrm{M}^{+}-\mathrm{C}_{9} \mathrm{H}_{8} \mathrm{~N} ; 2 \%\right), 130\left(\mathrm{C}_{9} \mathrm{H}_{8} \mathrm{~N}^{+}, 100 \%\right)$, $103\left(\mathrm{C}_{7} \mathrm{H}_{5} \mathrm{~N}^{+} ; 6 \%\right), 77\left(\mathrm{C}_{6} \mathrm{H}_{5}^{+} ; 8 \%\right)$.

\section{Acknowledgments}

We acknowledge the experimental work of Benedetta Frizzoni and Enrica Catalucci, ERASMUS students from Perugia University, financial support from CICYT SAF2003-03141, and a FPI fellowship to J. F. González.

\section{References}

1. Tew, K.D.; Bomber, A.M.; Hoffman, S.J. Cancer Res. 1988, 48, 3622.

2. See, for example, (a) Potentiation of the non-selective inhibitor ethacrynic acid in: O'Dwyer, P.; LaCreta, F.; Nash, S.; Tinsley, P.; Schidler, R.; Clapper, M.; Tew, K.; Panting, L.; Litwin, S.; Comis, R.; Ozols, R. Cancer Res. 1991, 51, 6059. (b) Design of isozyme-specific inhibitors in: Lyttle, M. H.; Hocker, M. D.; Hui, H. C.; Caldwell, C. G.; Aaron, D. T.; Engqvist-Goldstein, A.; Flatgaard, J. E.; Bauer, K. E. J. Med. Chem. 1994, 37, 189.

3. (a) Wang, A. L.; Tew, K. D. Cancer Treat. Rep. 1985, 69, 677. (b) Batist, G.; Tulpule, A.; Sinha, B.K.; Katki, A.G.; Myers, C.E.; Cowan, K.H. J. Biol. Chem. 1986, 25, 15544. (c) Buller, A.L.; Clapper, M.L.; Tew, K.D. Mol. Pharmacol. 1987, 31, 575. (d) Czerwinski M.; Gibbs J. P.; Slattery J. T Drug Metab. Dispos. 1996, 24, 1015.

4. (a) Samuelsson, B. Science 1983, 220, 568. (b) Ouwerkerk-Mahadevan, S.; Boom, J. H.; Dreef-Tromp, M. C.; Ploemen, J. H. T. M.; Meyer, D. J.; Mulder, G. J. Biochem. J. 1995, 308, 283.

5. Sipos, E. P.; Witham, T. F.; Ratan, R.; Burger, P. C.; Baraban, J.; Li, K. W.; Piantadosi, S.; Brem, H. Neurosurgery 2001, 48, 392. 
6. (a) Zhang, K.; Mack, T.; Kim, P.W. Int. J. Oncol. 1998, 12, 871. (b) Lyon R.P.; Hill, J. J.; Atkins, W. M. Biochemistry 2003, 42, 10418.

7. Bach, M. K.; Brashler, J. R.; White, G. J.; Galli, S. J. Biochem. Pharmacol. 1987, 36, 1461.

8. (a) Komagata, D.; Sawa, T.; Muroaka, Y.; Imada, C.; Okami, Y.; Takeuchi, T. J. Antibiot. 1992, 45, 1117. (b) Komagata, D.; Takahashi, Y.; Muraoka, Y.; Sawa, T.; Takeuchi, T. J. Antibiot. 1992, 45, 1122. (c) Komagata, D.; Sawa, R.; Kinoshita, N.; Imada, C.; Sawa, T.; Naganawa, H.; Hamada, M.; Okami, Y.; Takeuchi, T. J. Antibiot. 1992, 45, 1681.

9. (a) Kakinuma, K.; Rinehart, K. L. J. Antibiot. 1974, 27, 733. (b) Santamaría, A.; Cabezas, N.; Avendaño, C. Tetrahedron 1999, 55, 1173.

10. (a) Avendaño, C.; Menéndez, J. C. Curr. Med. Chem. 2002, 9, 159. (b) Avendaño, C.; Menéndez, J. C. Med. Chem. Rev.-Online 2004, 1, 419.

11. See, for example: Johnson, A.-J.; Janosik, T.; Bergman, J. ARKIVOC 2002, (viii), 55 and last papers on this topic from our laboratory: (a) González, J. F.; de la Cuesta, E.; Avendaño, C. Tetrahedron Lett. 2003, 44, 4395. (b) González, J. F.; de la Cuesta, E.; Avendaño, C. Synthetic Commun. 2004, 34, 1589. (c) González, J. F.; de la Cuesta, E.; Avendaño, C. Tetrahedron. 2004, 60, 6319.

12. The previously reported position of the methyl group was mainly based on the identification of $\alpha$-aminobutyric acid by thin-layer chromatography after hydrolysis. ${ }^{9 a}$

13. Radhakrishna, A. S.; Prasad, R. K.; Suri, S. K.; Sivaprakash, K.; Singh, B. B. Synth. Commun. 1991, 21, 379.

14. Hernández, F.; Lumetzberger, A.; Avendaño, C.; Söllhuber, M. Synlett 2001, 1387. 